\title{
Validity of G-36 and knowledge tests in relation to performance at a training program
}

\author{
Evidências de validade preditiva do G-36 e de \\ provas de conhecimento acadêmico em \\ relação ao desempenho no treinamento
}

\author{
Alina Gomide VASCONCELOS \\ Jáder dos Reis SAMPAIO \\ Elizabeth do NASCIMENTO'
}

\begin{abstract}
This study aimed to investigate the predictive validity of academic grades and G-36 scores in personnel selection. The sample was compose by 83 individuals from public organization with mean-age of 22.01 (SD=2.99) years old, being $81.9 \%$ males and 91.6\% with eleven years of education (High School at least). Pearson correlation and regression analysis were used to verify the association between training performance and both predictors. Significant correlations were observed between variables range. Linear regression indicated a shared variance of 23.0\% between G-36 and theoretical disciplines results. New research could be development to investigate the contribution of knowledge tests to personnel selection.
\end{abstract}

Uniterms: Cognitive ability; Education; Validity of tests.

\section{Resumo}

Este estudo teve como objetivo investigar a validade preditiva da nota na prova de conhecimentos acadêmicos e o escore no G-36 em relação ao desempenho no treinamento. A amostra foi composta por 83 candidatos de uma organização pública, com média de idade de 22,91 anos ( $D P=2,99$ ), sendo 81,9\% do sexo masculino e 98,8\% com nível médio de escolaridade. Dentre os resultados, não houve correlação significativa entre a nota na prova e as notas nas disciplinas no treinamento. Associações significativas, iguais a 0,5 e 0,41, foram obtidas entre o escore do G-36 e as disciplinas teóricas e práticas respectivamente. Análise de regressão linear indicou que o escore no G-36 apresenta uma variância compartilhada igual a 23,0\% em relação às disciplinas teóricas. Novas pesquisas deverão ser conduzidas para esclarecer os resultados do estudo e a contribuição das provas de conhecimentos amplamente utilizadas na seleção de pessoas em concursospúblicos.

Unitermos: Habilidade cognitive; Educação; Validade dos testes.

Studies demonstrated general cognitive ability ( $G$ factor) is an important predictor of several outcomes of everyday life including social accomplishments, academic achievement, job performance and creativity etc. (Kuncel, Hezlett \& One, 2004). The tools used to assess candidates' cognitive skills are widely used either in the

$\boldsymbol{\nabla \nabla \nabla \nabla}$

1 Universidade Federal de Minas Gerais, Faculdade de Filosofia e Ciências Humanas, Departamento de Psicologia. Av. Presidente Antônio Carlos, 6627, Sala 4048, Pampulha, 31270-90, Belo Horizonte, MG, Brasil. Correspondence to/Correspondência para:A.G.VASCONCELOS.E-mail:<alinagomide@gmail.com>. 
form of psychological tests, or knowledge tests in personnel selection.

According to Brazilian Federal Constitution, selection processes for public office should happen based on written tests of knowledge and titles so as to guarantee the democratization of accessibility to these jobs. In this sense, the application of objective psychological and knowledge tests in public contests meets the underlying constitutional principles relating to the legality, impersonality, administrative morality and publicity (Brasil, 1998; 2009). These resources are often used simultaneously in order to assess the cognitive capacity of candidates' for a certain job or position. However, greater importance is given to knowledge tests and it is assumed that good performance in these tests is related to applicants with greatest potential to carry out tasks at work (Queiroga, 2009).

Studies reported in literature identified a direct association between intelligence and occupational performance (Bertua, Anderson \& Salgado, 2005; Kuncel, et al., 2004; Mount, Barrick \& Strauss, 1999; Hough \& Oswald, 2000; Robertson \& Smith, 2001; Smith, 1994) as well as between performance at training programs (Schmidt \& Hunter, 1998; I.E Hunter \& R.F. Hunter, 1984). Salgado, Anderson, Moscoso, Bertua and De Fruyt (2003) conducted a meta-analytical study based on the results of an European sample of professionals in several areas in order to verify the predictive validity of general cognitive abilities and specific cognitive abilities (verbal, logical, special-mechanical, perceptual and memory) in relation to performance. General mental ability were an excellent predictor of performance at work $\left(_{\text {rcorrected }}=0.62\right)$, as well as the specific ability of memory $\left.{ }_{\text {rcorrected }}=0.56\right)$. Other abilities can also be considered as adequate predictors, for example: logical (rcorrected $=0.52$ ), perception ( rcorrected $=0.52$ ) and special-mechanical $\left(_{\text {rcorrected }}=0.51\right.$ ). The only exception was verbal abilities, which showed a lower association with performance $\left(_{\text {rcorected }}=0.35\right)$. The authors demonstrated two hypotheses to explain the low validity coefficient of verbal score in relation to the other abilities: a) existence of moderating variables and b) differences in the linguistic complexity according to the language in each country.

Results of meta-analytical research of Schmidt and Hunter (1998) indicated general intelligence factor

$68(\mathrm{G})$ as the best-isolated predictor of training performance
$\left.C_{\text {rcorrected }}=0.56\right)$ and job performance for individuals with no previous experience $\left({ }_{\text {rcorrected }}=0.51\right)$, despite the moderate magnitude validity coefficients (Tabachnick \& Fidell, 2001). When intelligence was combined with other measures of individual characteristics such as integrity, the predictive validity coefficient of performance in the task became higher $($ rcorrected $=0.65$ ). Schmidt and Hunter (2004) gathered several studies that reinforce the finding made by them in meta-analytical research from 1998. Results emphasize the $\mathrm{g}$ factor is the central construct in the job world. In a broader context, the general cognitive ability has been the best predictor of occupational level, training and job performances, when it compared to the predictive power of personality traits and specific cognitive abilities.

From sectional and longitudinal studies, the authors found that, despite some personality traits, in particular the conscientiousness factor of Big Five Model, also being significant predictors of occupational level, the individual could still achieve the career of his choice. The magnitude of this association tends to be small when compared to that observed between the $\mathrm{g}$ factor and occupational level.

Another issue discussed by the authors was the relevance of specific skills theory, which proposes that performance in different jobs require different cognitive abilities. Evidences carried out in ten years prior to the study developed by Schmidt and Hunter (2004) did not corroborate this hypothesis. The results showed that the measurements of specific skills produce a small increase in the coefficient of validity calculated from the $g$ measured, which can be explained by the fact that the tests of specific abilities evaluate, simultaneously, two different factors (general and specific). G remained as the responsible for job performance.

Kuncel et al. (2004) explain $G$ is an important predictor of job performance is because its relation to the acquisition of declarative knowledge (learning of facts, rules, principles and procedures) and procedural knowledge (knowing what and how to do in order to complete a task). Therefore, the $\mathrm{g}$ factor is directly associated with the ability to learn occupational function (Smith, 1994; Schmidt \& Hunter, 2004). In this sense, since $\mathrm{G}$ factor directly related to learning, one may conclude that a smarter individual tends to learn occupational functions more easily. Consequently, the individual will 
show a higher occupational performance in a shorter period of time when his performance is compared to an individual whose cognitive ability is similar or lower than the reference population's (Tracey, Sturman \& Tews, 2007).

Based on meta-analytical study conducted by Dye, Reck and McDaniel (1993), the predictive capacity of knowledge tests could be verified in relation to training and job performances ( $n=363,528$ individuals). The construct "knowledge" was understood as a set of facts, principles, concepts and other information relevant to job performance. The authors also considered two variables as moderating this relationship, namely, task similarity and task complexity. Corrected validity coefficients were 0.45 considering job performance and 0.47 for training performance. Moreover, it was observed that, more similarity between knowledge tests and job performance, the greater predictive power of the instrument used in the selection. Regarding task complexity, the best prediction rates were observed when performance was evaluated in more complex activities.

Queiroga (2009) examined to what degree job performance could predict the knowledge tests scores used at personnel selection. Job performance was measured by self-assessment as well as by their supervisors' performance rating. The sample consisted of 447 employees from two organizations (financial sector and energy sector). The positions required high school and university education levels and the tests were composed of items based on technical proficiency and general knowledge (for example, Portuguese). Correlation analysis indicated that the grades were associated with the results of self-report rating in one of organizations (correlation coefficient varied between 0.15 and $0.18 ; p<0.001$ ). The magnitude of the correlation was low. The hypothesis proposed to explain this result was the following: when there is higher convergence between the contents of the knowledge tests and the work activities so higher correlation could be observed between these variables. Furthermore, the author warned about the relevance of the use of general knowledge tests, since they could show no relation to the candidate's performance.

The present study was based on literature reported here, which emphases the importance to measure general cognitive ability in order to predict job performance. This literature indicates the use of knowledge and psychological tests to assess cognitive ability of candidates in the Brazilian context nowadays. In national literature, there are few studies conducted on the predictive validity of cognitive tests in personnel selection (Vasconcelos, 2010). In this sense, the objective of present study was to investigate the associations among intelligent test, knowledge grade and performance at a training program in a public state company. The main hypothesis was that cognitive abilities, as measured by an intelligence test and academic knowledge grade, would be predictors of training performance. Given the specificity of the organization studied, the grades of theoretical and practical subjects were used as training criterion performance.

\section{Method}

The study was developed from an exploratory associative research design. Furthermore, it can be classified as retrospective and a case study (Cozby, 2003), since associations were investigated between data collected from admission tests and information related to training performance in a single public state organization. The study was approved by the Research Ethics Committee of Universidade Federal de Minas Gerais.

\section{Participants}

Eighty three individuals participated in present study and they were admitted in a public assessment to compose the staff of a state public organization. The mean age was of 22.01 (Standard Deviation $=2.99$ ), 81.9\% were male, $91.6 \%$ were single, and $98.8 \%$ had a high school degree.

\section{Instruments}

a) Academic knowledge test: this test was announced in the edict of the public contest for a specific personnel selection. It was based on high school contents and it had eliminatory and classificatory power. It is composed by 50 questions and evaluated knowledge 
in the following areas: Portuguese, Brazilian Literature, Mathematics, Geography, History, Human Rights, Chemistry, Biology, Physics and Foreign Language (English or Spanish). The maximum score of the test was 100 points (official documents of the organization).

b) G-36 - Non-verbal intelligence test: psychological test developed by Boccalandro (2003) to be used at Brazilian context, particularly in the personnel selection. It is based on Spearman's theory to assess non-verbal general intelligence. It is composed by 36 items and may be applied without a time limit. The total score corresponds to the sum of correct answers in the test - maximum score being 36. In technical manual, instructions for application, correction and data interpretation are showed, as well as studies that indicated psychometric characteristics for the objectives proposed (Boccalandro, 2003). Concurrent validity in relation to the Dominos' test scores indicated a favorable result based on coefficient of 0.84 between the two instruments. The accuracy was calculated by the method of the two halves in relation to which a significant correlation between even items and odd items ( $r=0.82)$. Finally, the discriminative items capacity was studied by the bisserial-point correlation coefficient and it resulted in the rejection of four items. Consequently, the original test was reduced to 36 questions. Validity and reliability were kept in the final format of the test. New psychometric studies were conducted in 2001 and 2003 in order to update the norms (Boccalandro, 2003).

c) Training performance measures: training program is composed of 23 training subjects (instrumental and professional) (official documents of the organization). The names of the subjects are not mentioned here in order to maintain the confidentiality of the participating organization.

Tabel 1

Descriptive statistics of variables. Belo Horizonte, Brazil (May 2010)

\section{Procedures}

Data was obtained from documental analysis including research in digital and physical files of the organization. Descriptive statistical analysis was conducted in order to describe the sample and the variables of the study. Moreover, Pearson correlation analysis and simple linear regression were done to investigate the associations between the predictive measures (G-36 score and academic knowledge grade) and the mean grades from theoretical and practical subjects' training (dependent variables). Before the analysis, the grades at training program were grouped in two categories according to the predominant program contents: a) predominantly theoretical subjects and b) predominantly practical subjects. After grouping, the mean grade was calculated. A level of significance of $5 \%$ was adopted for data analysis.

\section{Results}

Descriptive statistics for the G-36 score regarding the grades in the general knowledge test and in the training program are showed in Table 1. Coefficients of skewness and kurtosis indicated that variables tend to normal distribution (Tabachnick \& Fidel, 2001).

Table 2 shows the Pearson correlation coefficients among variables analyzed in present study. Raw scores of participants' in G-36 showed significant correlations (0.48 and 0.43 ) with the mean grades in the theoretical and practical subjects respectively.

Such correlations were positive and moderate. However, no significant correlation between academic knowledge test and the mean grade in theoretical and practical subjects were found ( $r=-0.12$ and $-0.12 ; p=0.30$ ). Moreover, the correlation between the grade in academic knowledge test and the non-verbal

\begin{tabular}{|c|c|c|c|c|c|c|c|}
\hline Variables & $N$ & Minimum & Maximum & Mean & SD & Skewness & Kurtosis \\
\hline G36 - total score & 83 & 16 & 34 & 28.48 & 3.79 & -0.91 & 0.85 \\
\hline Knowlegde test & 83 & 66 & 88 & 73.86 & 5.01 & 0.35 & -0.30 \\
\hline Theoretical subjects & 83 & 7.13 & 9.38 & 8.14 & 0.46 & -0.25 & 0.00 \\
\hline Pratical subjects & 83 & 7.87 & 9.33 & 8.66 & 0.33 & -0.17 & -0.41 \\
\hline
\end{tabular}

Note: SD: Standard Deviation. 
Tabel 2

Pearson correlations. Belo Horizonte, Brazil (May 2010)

\begin{tabular}{lccc}
\hline Variables & Theoretical subjects & Practical subjects & Knowledge test \\
\hline G-36- total score & $0.48^{*}$ & $0.43^{*}$ & 0.13 \\
Theoretical subjects & & $0.51^{*}$ & -0.12 \\
Pratical subjects & & -0.12 \\
\hline
\end{tabular}

Note: ${ }^{*} p<0.001$

Tabel 3

Simple linear regression model for Theoretical Discipline Mean. Belo Horizonte, Brazil (May 2010)

\begin{tabular}{|c|c|c|c|c|c|c|}
\hline \multirow{2}{*}{ Variables } & \multirow{2}{*}{ B } & \multirow{2}{*}{ SE } & \multirow{2}{*}{ Std. Coef. } & \multirow{2}{*}{ t } & \multicolumn{2}{|c|}{ IC } \\
\hline & & & & & Lower bound & Upper bound \\
\hline (Constant) & 6.54 & 0.34 & & $19.18^{*}$ & 5.86 & 7.22 \\
\hline G36 - total score & 0.06 & 0.01 & 0.47 & $4.75^{*}$ & 0.03 & 0.08 \\
\hline$R^{2}$ & 0.23 & & & & & \\
\hline N & 0.83 & & & & & \\
\hline
\end{tabular}

Note: ${ }^{*}<<0.001$

Dependent variabel: theoretical mean grades; SE: Standardized Error; Std. Coef.: Standardized Coefficient; IC: Confidence Intervals.

Tabel 4

Regression linear models for practical subjects. Belo Horizonte, Brazil (May 2010)

\begin{tabular}{|c|c|c|c|c|c|c|}
\hline \multirow{2}{*}{ Variables } & \multirow{2}{*}{ B } & \multirow{2}{*}{ SE } & \multirow{2}{*}{ Std. Coef. } & \multirow{2}{*}{$t$} & \multicolumn{2}{|c|}{ IC } \\
\hline & & & & & Lower bound & Upper bound \\
\hline (Constant) & 7.59 & 0.25 & & $30.85^{*}$ & 7.10 & 8.07 \\
\hline G36 - total score & 0.04 & 0.01 & 0.44 & $4.40^{*}$ & 0.02 & 0.06 \\
\hline$R^{2}$ & 0.19 & & & & & \\
\hline$N$ & 0.83 & & & & & \\
\hline
\end{tabular}

Note: $" p<0.001$

Dependent variabel: theoretical mean grades; SE: Standardized Error; Std. Coef.: Standardized Coefficient; IC: Confidence Intervals.

intelligence score was weak and not significant $(r=-0.13$; $p=0.26)$.

In order to better understand the significant associations, simple linear regression models were adjusted to mean grades in training theoretical and practical subjects and to total score in G-36. The main results of the first model are showed in Table 3.

The model showed the following equation of regression for the dependent variable Theoretical Subjects Mean: $\hat{\gamma}=6.52+0.06 \mathrm{G}-36$, the model being $(\mathrm{F}=22.58 ; p<0.001) . R^{2}(0.23)$ indicated score in the general intelligence test explains $23 \%$ of the variation in performance in grade in theoretical subjects. Results of the second regression model are showed in Table 4.

Mean grade in practical training subjects were used as a dependent variable in the regression model and the following equation of regression was obtained: $\hat{\gamma}=7.59+0.04 G-36$, the model being ( $F=19.39 ; p<0.001)$. $R^{2}(0.18)$ indicated that the independent variable, score in the general intelligence test, explains 18\% of the variation in performance in the grades of the practical subjects.

\section{Discussion}

Results indicated that individuals with higher general cognitive ability had higher scores in training measures. Linear regression analysis partially confirmed this association. G-36 score explained 23\% of the variance in theoretical subject grade and $18 \%$ of practical subject. It was observed, therefore, a difference between results according to the contents of the subjects. A possible 
explanation is that other individual variables contribute to the explanation of most of the variation of grades in practical training, for example, psychomotor variables, which were not evaluated in this study.

In general, results corroborate several researches in the field that general intelligence test is a good predictors of individuals' learning measures (Schmidt, 2002; Outtz, 2002; Schimdt \& Hunter, 1998; Tracey, Sturman \& Tews, 2007). It can be observed, however, that results obtained by Schimdt and Hunter (1998) indicate that $31 \%$ of the variance of performance at a training program was explained by general cognitive ability, a higher value than the one obtained in present study. A hypothesis to clarify this difference was the low variability of scores in G-36 in this study, which may indicate that items could be relatively easy for most candidates approved in the first phase of personnel selection process. Low variability impairs the subsequent association with performance grades obtained in training program that also indicated restricted amplitude.

Academic knowledge score, however, did not show any association with the theoretical subjects. This result was differently from what has been expected and could suggest that the score in the general knowledge test was not a valid predictive variable of training performance in this study. However, intelligence assessed by psychological tests has offered more useful information about training performance. A plausible explanation for the lack of association between academic knowledge test, G-36 score and performance at a training program may be the fact that the evidence of academic achievement, as formulated, assesses content that was not related to general ability of problem solving or to relevant aspects of the training content for the occupational function. It could be inferred that cognitive demands required for solving questions and the contents of $t$ academic knowledge test based on the contents taught in high school were not related to relevant aspects of performance in the theoretical subjects of training program.

Together with the evidences showed by Queiroga (2009), our results suggest that the use of general knowledge tests may not useful to purpose of helping the selection of candidates that could have higher 72 performances in-work and training program. As recommend by Dye, Reck and McDaniel (1993) and Queiroga (2009), knowledge tests based on contents specifically related to the job could be more pertinent in personnel selection.

\section{Final Considerations}

Results achieved in the present study, although limited to a single public state organization, are consistent with the literature reported. Individual characteristics contribute in understanding one's performance at job context. In particular, results emphasized the importance to choose adequate predictive and criterion measures for assessing job performance. Evidence accumulated over decades emphasizes intelligence assessment relevance as an important psychological predictive variable of job performance (Bertua et al., 2005; Hough \& Oswald, 2000; Kuncel et al., 2004; Mount et al., 1999; Robertson \& Smith, 2001; Schmidt \& Hunter, 1998; Smith, 1994). The results reported here also reinforced such finding. However, a question is raised when one considers which measure of intelligence to use. It was found that the psychological test chosen by the organization could not has been the most suitable for its intended purpose, because of low variability of candidates performance in present study. This finding confirmed the importance of developing local systematic studies to identify satisfactory predictive measures that are more suitable for the specific organizational context (American Psychological Association, 1999).

Discussions about the convergence between the contents of the academic knowledge test and job performance suggest the use of strict procedures in defining the content of tests, otherwise the results obtained may be arbitrary and unhelpful for making decision in personnel selection. For such, it is recommended that academic knowledge tests used in the context of personnel selection be developed and analyzed in the same way as psychological tests and educational tests. For example, similar as Ministry of Education and Culture evaluates high school and university learning (Exame Nacional de Desempenho de Estudantes - ENEM and Exame Nacional de Ensino 
Médio-ENAD). Psychometric techniques available could identify which items have greater predictive power in relation to the expected performance, for example, in training program. Use of validity knowledge tests could contribute to more efficient decision making in the selection process, which could increase the chances of success in choosing the best candidates.

Another aspect to be considered refers to investigate the supervisors' ratings that could influence in the relationship between knowledge tests grades and training performance. Literature indicates that subjective aspects may influence the rates instructors give their students (Hogan, 2006). Considering that, it is suggested that tests could be developed by an independent commission and based on content and criteria defined in consensus with the instructors. This strategy is widely used in other organizations and allows instructors to focus their attention on the training, since they are evaluated by others, which prevents that subjective and relational aspects interfere in the evaluation process. The instructors are also challenged because they must propose incisive assessment with the content in order to avoid contradictory actions of the ones being trained and to provide useful information to organization.

This research reported a specific personnel selection and allowed us to point directions for improving it to the organization. This study reinforces the recommendation about the importance of developing systematic investigations about psychometric qualities of predictive measures, as well as the job related criterion, considering the peculiarities of the contexts and purposes that justify its use. In a theoretical point of view, the results contribute to better understand specific constructs that are relevant in the organizational context, such as job performance and intelligence. The latter is the psychological construct more widely considered in the investigation of the personal characteristics that influence occupational performance.

\section{References}

American Psychological Association. (1999). Standards for educational and psychological testing. Washington, DC: Author.
Bertua, C., Anderson, N., \& Salgado, J.F. (2005). The predictive validity of cognitive ability tests: A UK meta-analysis. Journal of Occupational and Organizational Psychology, 78 (3), 387-409.

Boccalandro, E. R. (2003). G-36: teste não verbal de inteligência - Manual. São Paulo: Vetor.

Brasil. (1998). Constituição da República Federativa do Brasil: Promulgada em 5 de outubro de 1988. São Paulo: Saraiva.

Brasil. (2009 24 de agosto). Decreto no 6.944, estabelece medidas organizacionais para o aprimoramento da administração pública federal direta, autárquica e fundacional, dispõe sobre normas gerais relativas a concursos públicos, organiza sob a forma de sistema as atividades de organização e inovação institucional do Governo Federal, e dá outras providências. Diário Oficial da União, Seção I. Recuperado em junho 22, 2010, disponível em: <http://www.planalto.gov.br/ccivil_03/ _Ato2007-2010/2009/Decreto/D6944.htm>.

Cozby, P. C. (2003). Métodos de pesquisa em ciências do comportamento. São Paulo: Atlas.

Dye, D. A., Reck, M., \& McDaniel, M. A. (1993). The validity of job knowledge measures. International Journal of Selection and Assessment, 1(3),153-157.

Hogan, T. P. (2006). Introdução a pratica de testes psicológicos. Rio de Janeiro: LTC.

Hough, L. M., \& Oswald, F. L. (2000). Personnel selection: Looking toward the future remembering the past. Annual Review of Psychology, 51, 631-664.

Hunter, J. E., \& Hunter, R. F. (1984). Validity and utility of alternative predictors of job performance. Psychological Bulletin, 96(1), 72-98.

Kuncel, N. R., Hezlett, S. A., \& Ones, D. S. (2004). Academic performance, career potential, creativity, and job performance: Can one construct predict them all? Journal of Personality and Social Psychology, 86(1),148-161.

Mount, M. K., Barrick, M. R., \& Strauss, J. P. (1999). The joint relationship of counscientioness and ability with performance: Test of the interaction hypothesis. Journal of Management, 25(5), 707-716.

Outtz, J. L. (2002). The role of cognitive ability tests in employment selection. Human Performance, 15(1/2), 161-171.

Queiroga, F. (2009). Seleção de pessoas e desempenho no trabalho: um estudo sobre a validade preditiva dos testes de conhecimentos (Tese de doutorado não-publicada). Programa de Psicologia Social do Trabalho e das Organizações, Universidade de Brasília.

Robertson, I. T., \& Smith, M. (2001). Personnel selection. Journal of Occupational and Organizational Psychological, 74, 441-472.

Salgado, J. F., Anderson, N., Moscoso, S., Bertua, C., \& De Fruyt, F. (2003). International validity generalization of GMA and cognitive abilities: A European community meta-analysis. Personnel Psychology, 56(3), 573-606.

Smith, M. (1994). A theory of the validity of predictors in selection. Journal of Occupational and Organizational Psychology, 67(1), 13-19. 
Schmidt, F. L., \& Hunter, J. E. (1998). The validity and utility of selection methods in personnel psychology: Practical and theoretical implications of 85 years of research findings. Psychological Bulletin, 124(2), 262-274.

Schmidt, F. L., \& Hunter, J. E. (2004). General mental ability in the world of work: Occupational attainment and job performance. Journal of Personality and Social Psychology, 86(1), 162-173.

Schmidt, F. L. (2002). The role of general cognitive ability and job performance: Why there cannot be a debate. Human Performance, 15(1/2), 187-210.

Tabachnick, B. G., \& Fidell, L. S. (2001). Using multivariate statistics ( $2^{\text {nd }}$ ed.). New York: HarperCollins.
Tracey, B. T., Sturman, C. M., \& Tews, M., J. (2007). Ability versus personality: Factors that predict employee job performance. Cornell University, 48(3), 313-322.

Vasconcelos, A. G. (2010). Evidências de validade preditiva de medidas psicológicas em relação ao desempenho no trabalho: um estudo de caso em uma organização militar (Dissertação de mestrado não-publicada). Programa de Pós-Graduação em Psicologia, Universidade Federal de Minas Gerais, Belo Horizonte.

Received on: 14/3/2012

Approved on: 16/4/2012 